\title{
STUDY THE NEPHRO-PROTECTIVE EFFECTS OF LOSARTAN ON RATS
}

BY

\author{
Hosny A Elewa 1
}

\section{FORM}

\author{
1 Department of Clinical and hospital Pharmacy, Faculty of Pharmacy, \\ Taibah University, KSA
}

\begin{abstract}
In the Reduction of Endpoints in NIDDM (noninsulin-dependent diabetes mellitus) with the Angiotensin II Antagonist Losartan study (RENAAL study), Losartan reduced the risk of the doubling of serum creatinine concentration by $25 \%$ and of end stage renal disease (ESRD) by $28 \%$. Methods: 40 albino rats were enrolled in this study, and they were divided into four main groups, each group 10 rats. Where, group I, serves as a control, and group II was treated with Gentamicin $80 \mathrm{mg} / \mathrm{kg}$. The group III was treated with Losartan. While, group IV was treated with Losartan and Gentamicin. Results: showed that Losartan has statistically significant nephro-protective effects. Their nephro-protective effects were assessed by:-1histopathological studies. 2- Measuring serum levels of BUN, and, creatinnine. Conclusions: Losartan has renal-protective effects.
\end{abstract}

Key words: Nephro-protective effects - Losartan - Gentamicin

\section{Introduction:}

Losartan $50 \mathrm{mg}$ resulted in significant reductions of systolic and diastolic blood pressure at 24 hours after dosing. Approximately $70 \%$ of the maximal reduction had occurred by one week of therapy (Gradman et al., 1995). In patients with type 2 diabetes mellitus, Angiotensin II receptor blockers (ARBs) are especially effective for decreasing nephropathy progression rate, independent of their blood pressure-lowering effect. In the Reduction of Endpoints in NIDDM (noninsulin-dependent diabetes mellitus) with the Angiotensin II Antagonist Losartan study (RENAAL study), Losartan reduced the risk of the doubling of serum creatinine concentration by $25 \%$ and of end stage renal disease (ESRD) by $28 \%$ (Brenner et al., 2001).

The decreased risks of ESRD (26\%) and or death (19\%) remained unchanged after adjustment for blood pressure, indicating reno-protection was independent of blood pressure reduction (Brenner et al., 2001). Losartan has been found to down-regulate the expression of transforming growth factor beta (TGF- $\beta$ ) types I and II receptors in the kidney of diabetic rats, which may partially account for its nephro-protective effects (Guo and Qiu, 2003).

\section{Material and Methods:}

\section{Animals:-}

Male albino rats weighing $(130 \pm 20 \mathrm{gm})$ were obtained from the animal house of Al-Nile Pharmaceutical Company. They were housed in stainless steel cages under a 12 hours light / dark cycle at room temperature. Animals were kept under the same condltion with regard food and water all over the period of this study. Each individual animal was weighed before start of therapy and was clearly marked by gentian violet to indicate its weight. The doses of drugs were accurately calculated according to the weight of each animal. 


\section{Apparatuses:}

1. Centrifuge.VEB MLW Zentrifugenbav engelsdorf type T52.1.

2. Spectrophotometer "Shimadzu, UV-visible recording spectrophotometer UV-160, Shimadzu Corporation Kyoto-Japan”.

\section{Drugs and chemicals:}

In this study, the following drugs and chemicals were used:

1- Gentamicin sulphate $80 \mathrm{mg} / \mathrm{ml}$ (Epigent) was obtained from: E.I.P.I.Co.

2- Losartan (50mg. tab. - Amriya comp).

3- Urea and creatinine kits.

\section{Induction of Nephropathy in Rats:}

The rats received ordinary rat diet for 6 weeks and were given gentamicin injection in a dose of $80 \mathrm{mg} / \mathrm{kg}$ intraperitoneal (IP) once daily (Joel et al., 2002) during the last 8 consecutive days.

\section{Study design:}

Animals were randomized after estimation of basal blood urea and serum creatinine into four groups as follows:

\section{Group I (Control group)}

10 rats received ordinary rat diet for 6 weeks, received $\mathrm{Na} \mathrm{Cl} 0.9 \%$ intraperitoneal (IP) in equivalent volume as gentamicin treated rats in the last 8 consecutive days, and served as control group.

\section{Group II (Gentamicin group)}

10 rats received ordinary rat diet for 6 weeks and were given gentamicin injection in a dose of $80 \mathrm{mg} / \mathrm{kg}$ intraperitoneal (IP) once daily (Joel et al., 2002, Sakthi et al 2010) during the last 8 consecutive days

\section{Group III (Losartan group)}

10 rats received ordinary rat diet for 6 weeks and receive Losartan $10 \mathrm{mg} / \mathrm{kg} /$ day orally by gastric tube concomitant with the ordinary diet (Takashi et al., 2002).

\section{Group IV (Losartan and gentamicin group)}

10 rats received ordinary rat diet concomitant with Losartan $10 \mathrm{mg} / \mathrm{kg} /$ day orally by gastric tube for 6 weeks, and gentamicin injections ( $80 \mathrm{mg} / \mathrm{kg} /$ day) intraperitoneal (IP) once daily in the last 8 consecutive days. (Cau et al., 2008).

\section{Samples collection:}

The animals were anaesthetized using diethyl ether. Blood samples were drawn from the venousplexus deep to the medial canthus of the palpebral fissure. $5 \mathrm{ml}$ blood were added to an anticoagulant ( EDTA) centrifuged at 2,000 rpm for $10 \mathrm{~min}$ at $4^{\circ} \mathrm{C}$ to separate plasma from erythrocytes. The biochemical parameters were determined as follows.

\section{Biochemical analysis and technique:}

1. Serum urea (measured in $\mathrm{mg} / \mathrm{dl}$ ).

2. Serum creatinine (measured in $\mathrm{mg} / \mathrm{dl}$ ). 


\section{Determination of serum urea:}

Blood urea levels were determined following urease modifled berthelot reaction (Fawcett and Scott, 1960) using kit supplied by Biomerieux- France.

\section{Reagents:}

1. Reagent 1 (standard): urea $50 \mathrm{mg} / \mathrm{dl}$.

2. Reagent 2 (enzyme): urease

3. Reagent 3 (color reagent): phosphate buffer $(\mathrm{PH}=0.8)$, sodium salicylate, sodium nitroprusside and ethylenediaminotetra-acetic acid (EDTA).

4. Reagent 4 (alkaline reagent): sodium carbonate and sodium hypochloride

5. Working reagent: one bottel of reagent 3 was reconstituted with one vial of reagent 2 and shacked gently.

\section{Procedure:}

1. $1 \mathrm{ml}$ of working solution was pipetted into 3 test tubes (test, blank and standard)

2. $10 \mathrm{ul}$ of tested serum sample and $10 \mathrm{ul}$ of standard solution were added to their corresponding tubes.

3. The tubes were mixed and incubated at $37 \mathrm{C}^{\circ}$ for 3 minutes.

4. 200ul of reagent 4 was added to each ofthe three tubes.

5. The tubes were mixed and incubated at $37 \mathrm{C}^{\circ}$ for 5 minutes

6. The absorbance was read using a spectrophotometer at wave length of $580 \mathrm{~nm}$ and setting the blank at zero.

\section{Calculation:}

$$
\text { Serum urea }=\frac{A \text { bsorbance } A \text { sample }}{A \text { bsorbance } A \text { standard }} \quad \text { X 50. mg/dl. }
$$

\section{Determination of serum creatinine}

Serum creatinine was determined by kinetic measurements according to the methods of (Bartels, 1971) using kit supplied by Human-Germany.

\section{Principle:}

The complex formed by creatinine and picric acid in an alkaline medium is measured for two minute

\section{Reagents:}

1. Reagent 1 (standard): creatmine $2 \mathrm{mg} / \mathrm{dl}$.

2. Reagent 2 (colour reagent): picric acid.

3. Reagent 3 (alkaline reagent): sodium hydroxide diluted with distilled water in the ratio $1: 4$.

4. Working reagent: one volume of reagent 2 was mixed with one volume of reagent 3.

\section{Procedure:}

1. $1 \mathrm{ml}$ of working solution was pipetted into 2 cuvettes (test and standard).

2. $100 \mathrm{ul}$ of tested serum sample and $100 \mathrm{ul}$ of standard solution were added to their corresponding cuvettes.

3. The cuvettes were mixed and stopwatch was started immediately.

4. The absorbance was read using a spectrophotometer at wave length of $492 \mathrm{~nm}$ between $\mathrm{t}=20 \mathrm{sec}$ and $\mathrm{t}=80 \mathrm{sec}$ where the zero adjustment was the air.

\section{Caculation:}

Serum creatinme $(\mathrm{mg} / \mathrm{dl})=\frac{\Delta \text { A sample }}{\Delta \text { A standard }} \quad$ X $2 \quad \Delta \mathrm{A}=\mathrm{A}_{2}-\mathrm{A}_{1}$

$A_{2}$ : absorbance 60 seconds after first measurement $A_{1}$. 
$\mathrm{A}_{1}$ : absorbance at 20 seconds.

\section{Collection of kidney for histopathological examination:}

At the end of $6^{\text {th }}$ week after drug or vehicles administration the animals were sacrificed and the kidneys were removed for histological and ultra structure examination. One kidney was cut longitudinally; one half was fixed in $10 \%$ buffered formalin and embedded in paraffin. Sections of 5-mm thickness were cut and stained with Mayer's hematoxyline and eosin (for examination of cell structure) and examined by light microscope (Kelly et al., 2000).

\section{Statistical analysis of results:}

The variability of results was expressed as the mean \pm standard deviation $(X \pm S D)$. Statistical analysis of the difference between groups was performed by using Statistical package for the social Sciences (SPSS) version 20, using one-way analysis of variance (ANOVA), and paired T test. Charts were done using Excel program, Microsoft Office XP 2007.

\section{Degree of significance:}

$\mathrm{P}>0.05=$ insignificant difference.

$\mathrm{P}<0.05=$ significant difference.

\section{RESULTS:}

\section{Serum urea:}

The mean of serum urea levels of the control group was $28.2 \pm 1.5 \mathrm{mg} / \mathrm{dl}$, and in gentamicin treated group was $92.3 \pm 1.2 \mathrm{mg} / \mathrm{dl}$. This level showed a significant increase compared to the control group $(\mathrm{P}<0.05)$.

Our study found that in Losartan treated group the mean serum levels of urea was $25.2 \pm 0.9 \mathrm{mg} / \mathrm{dl}$. This level showed no significant change compared to control group $(28.2 \pm 1.5 \mathrm{mg} / \mathrm{dl})$, This study found that gentamicin and Losartan treated group, thier mean serum urea levels was $60.4 \pm 1.2 \mathrm{mg} / \mathrm{dl}$. The statistical analysis indicate that the serum levels of urea showed a significant decrease as compared to that levels of gentamicin treated group which was $92.3 \pm 1.2 \mathrm{mg} / \mathrm{dl}$ by using paired $\mathrm{T}$ test the $\mathrm{P}$ value $<0.05$.

\section{Serum creatinine:}

Our results expressed as mean \pm SD (Table (1), Figure (2) show that in the control group, the mean of serum levels of creatinine was $0.62 \pm 0.05 \mathrm{mg} / \mathrm{dl}$, and in group treated with gentamicin ,the mean of serum levels of creatinine was $2.7 \pm 0.09 \mathrm{mg} / \mathrm{dl}$. This level showed a significant increase compared to control group $(\mathrm{P}<0.05)$.

The results obtained for group treated with Losartan, the mean of serum levels of creatinine was $0.63 \pm 0.03 \mathrm{mg} / \mathrm{dl}$. This value showed no statistically significant change compared to control group. In gentamicin and Losartan treated group, the mean of serum levels of creatinine was $0.98 \pm 0.08 \mathrm{mg} / \mathrm{dl}$, this value showed a statistically significant decrease compared to gentamicin treated group $(\mathrm{P}<0.05)$. The results proved that Losartan has a nephroprotective effects. 
Table (1): Shows the Effects of oral administration of Losartan ( in absence and presence of gentamicin ) on serum urea(mg/dl), and, serum creatinine $(\mathrm{mg} / \mathrm{dl})$ in rats treated groups.

\begin{tabular}{|lcc|}
\hline Treatments & $\begin{array}{c}\text { Serum urea } \\
(\mathrm{mg} / \mathrm{dl})\end{array}$ & $\begin{array}{c}\text { Serum creatinine } \\
(\mathrm{mg} / \mathrm{dl})\end{array}$ \\
\hline Control & $28.2 \pm 1.5$ & $0.64 \pm 0.07$ \\
Gentamicin & $92.3 \pm 1.2^{*}$ & $3.12 \pm 0.37^{*}$ \\
Losartan & $25.2 \pm 0.9$ & $0.63 \pm 0.02$ \\
Losartan with Gentamicin & $62.2 \pm 1.6^{-}$ & $1.32 \pm 0.27^{-}$ \\
\hline
\end{tabular}

All data are mean \pm Standard deviation (SD).

*Significant increase from normal control group.

-Significant decrease from gentamicin treated group.

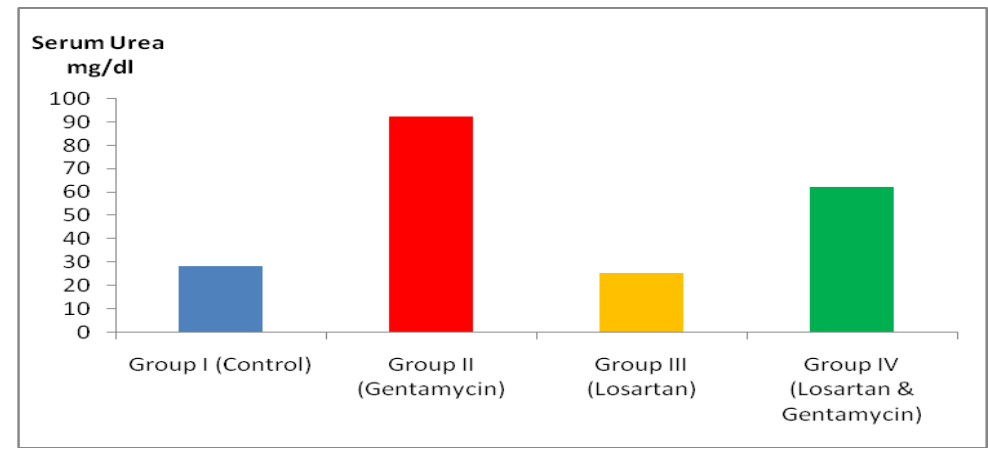

Fig. (1): Shows the effects of different treatments of groups: (control gp, gentamicin treated gp., Losartan gp., Losartan with Gentamicin gp) on the mean serum levels of urea $(\mathrm{mg} / \mathrm{dl})$.

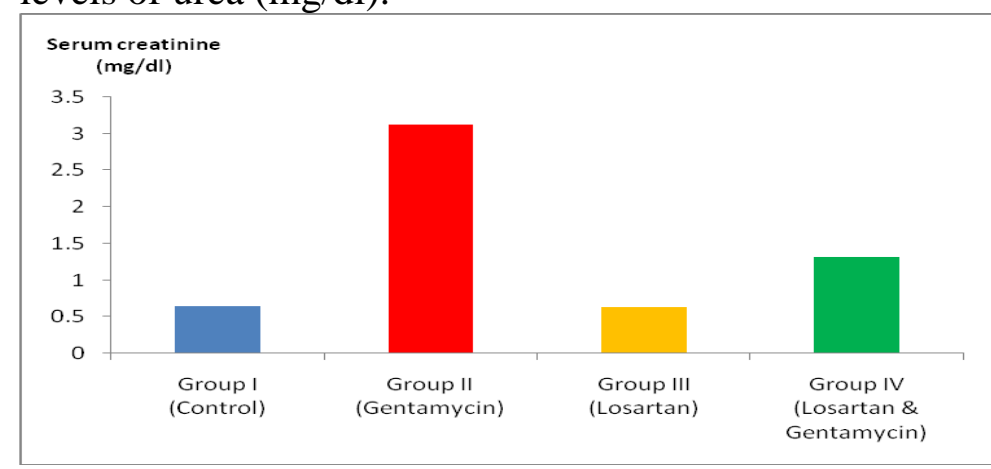

Fig. (2): Shows the effects of different treatment of groups : (control gp, gentamicin treated gp., Losartan gp., Losartan with Gentamicin gp. ) on the mean serum levels of creatinine $(\mathrm{mg} / \mathrm{dl})$. 


\section{Histopathology}

In the control group, section of rat kidney shows normal appearance of glomeruli and tubules, (figure 3). In gentamicin treated group, section of rat kidney shows dilatation of the tubules with drop out of some epithelial lining (picture of tubular necrosis), (figure 4).

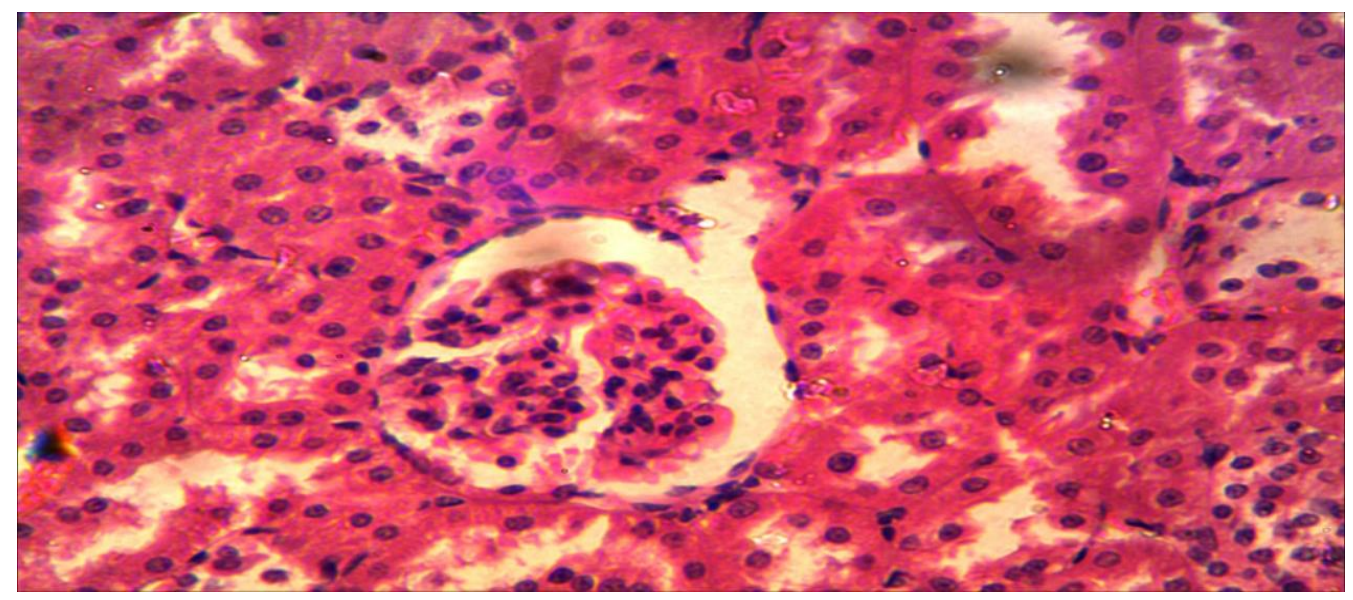

Fig. (3): Section from the rat kidney of control group showed normal appearance of glomeruli and tubules,[( H\& E) X 400].

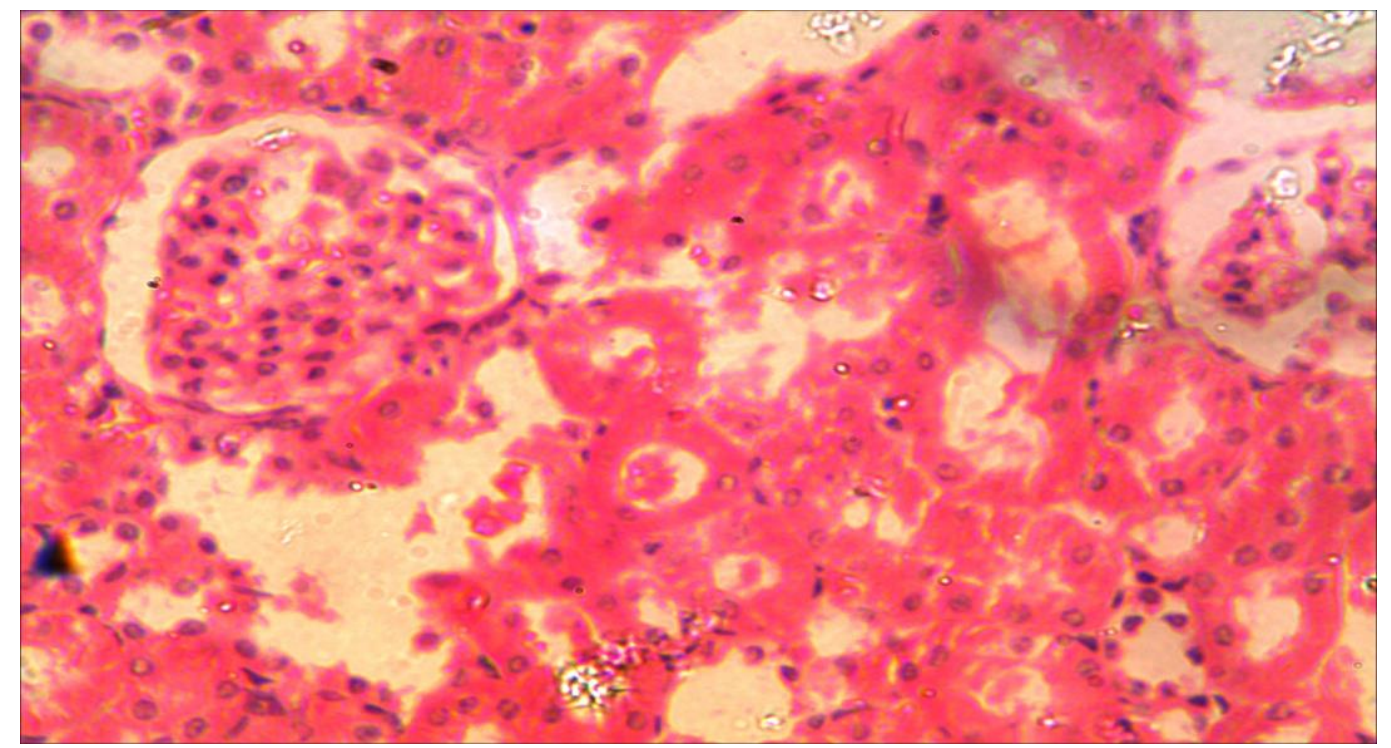

Fig. (4): Section from the rat kidney of gentamicin treated group shows dilatation of the tubules with drop out of some epithelial lining, (picture of tubular necrosis), [( H\& E) X 400].

In Losartan treated rats, animals show normal appearance of glomeruli and tubules. While, that treated with gentamicin and, Losartan show apparently minimal glomerular atrophy and minimal tubular heamorrhge.

\section{DISCUSSION}

The present study was designed to investigate the possible potential renoprotective role of Losartan in gentamicin induced nephrotoxicity in rats.

Rats are suitable models of experimental animals for studying the gentamicin nephrotoxicity. This was evidenced when toxic effects of gentamicin on several enzyme 
activities of kidney were compared between rats and mice, it was found that rat serum urea concentration was significantly increased in gentamicin nephrotoxicity while no change occur in mice (Suzuki et al., 1995).

In the present work histopathologically (in gentamicin injected animals), the kidney sections showed dilatation of the tubules with drop out of some epithelial lining, (picture of tubular necrosis), (figure 4).

In accordance with (Abdel-Raheem et al., 2010) our results in sections from control group showed normal histological structure of the glomeruli and renal tubules in the cortex and normal tubules in the medulla, (figure 3).

But in renal sections from gentamicin-treated rats, the glomeruli showed atrophy in some of them and hypertrophy in others, also there were degeneration and necrosis in the epithelial cells lining the renal tubules with cystic luminal dilatation in others at the cortex. Mononuclear leucocytes inflammatory cells infiltration was observed in focal manner between the tubules in the corticomedullary junction as well as in the perivascular area of the dilated blood vessels associated with edema, (figure 4).

These results were in line with the result obtained by (Naidu et al., 2000) and (Joel et al., 2002) they reported that gentamicin treated rats showed in addition to the necrosis of proximal tubules formation of hyaline casts and dilatation of distal tubules. In addition Sandhya et al., (1995) reported that gentamicin treated rats showed the presence of homogenous materials in the form of droplets of masses in proximal convoluted tubules in addition to inflammatory filtrates in the interstitium and these changes were markedly reduced by lipoic acid treatment.

In the present study Losartan administration, to the rats injected with gentamicin showed marked improvement of renal function (significant decrease in serum urea and creatinine). The previous results agree with Heeba et al. (2011) who showed that treatment with Losartan significantly reduced blood urea nitrogen (BUN) and serum creatinine levels elevated by gentamicin administration. Also, Losartan significantly attenuated gentamicin -induced increase in malondialdehyde and decrease in reduced glutathione, catalase and superoxide dismutase activities in renal cortical homogenates which is proved by Hall $\mathbf{A}$, and et al (2009), and Herrera et al (2010) they found a strong correlation between loss of peroxiredoxin $2\left(\operatorname{Prdx}_{2}\right)$ and podocyte apoptosis and proteinuria was also demonstrated in the Ang II-infused rats.

Additionally, histopathological examination and scoring showed that Losartan markedly ameliorated gentamicin -induced renal tubular damage.

On the basis of previous results, it is proved that Losartan has great renoprotective effects, so it is advised to use Losartan in patients having renal troubles especially in ischemic nephropathy and hypertension.

\section{Acknowledgement}

We take this opportunity to show our greatest appreciation to Dr. Zeinab Alkasaby Zalat

\section{REFERENCES}

Abdel-Raheem, I.; EL-Sherbiny, G.; and Taye, A. (2010): green tea ameliorates renal oxidative damage induced by gentamicin in rats, Pak. J. Pharm. Sci., Vol.23, No.1, January, pp.21-28.

Bartels, H. (1971): Modified method of bartels for kinetic measurements.Clinc. Chim. Acta., 32, 81. 
Brenner, BM. ; Cooper, ME.; de Zeeuw, D.; Keane, WF.; Mitch, WE. and Parving, HH. for the Renal Study Investigators. (2001): Effects of losartan on renal and cardiovascular outcomes in patients with type 2 diabetes and nephropathy. $\mathrm{N}$ Engl $\mathbf{J}$ Med.; 345 : 861-869.

Cau, J.; Frederic, F.; Jean Paul, T.; Lilach O., Thierry, H.; and Jean Michel, G. (2008) Trimetazidine reduces early and long-term effects of experimental renal warm ischemia: A dose effect study.Journal of vascular surgery Volume 47:45-49.

Fawcett, j.K. and Scott, J.E. (1960): Determination of urea (urease-modified berthelot reaction). J. Clin. Path., 13:156-159.

Gradman, AH.; Arcuri, KE.; Goldberg, AI.; Ikeda, LS.; Nelson, EB.; Snavely, DB. and Sweet, CS. (1995):A randomized, placebo controlled, double-blind, parallel study of various doses of losartan potassium compared with enalapril maleate in patients with essential hypertension. Hypertension.; 25: 1345-1350.

Guo, ZX. and Qiu, MC. (2003): "Losartan downregulates the expression of transforming growth factor beta type I and type II receptors in kidney of diabetic rat] (in Chinese). Zhonghua Nei Ke Za Zhi 42 (6): 403-408.

Hall A, Karplus PA, Poole LB (2009): Typical 2-Cys peroxiredoxins-structures, mechanisms and functions. FEBS J; 276: 2469-2477.

Heeba , G.; Karger, A.; and Basel. (2011): Angiotensin II receptor blocker, losartan, ameliorates gentamicin-induced oxidative stress and nephrotoxicity in rats. Pharmacology. ;87(3-4):232-240.

Herrera M, Silva GB, Garvin JL. (2010): Angiotensin II stimulates thick ascending limb superoxide production via protein kinase C(alpha)-dependent NADPH oxidase activation. J Biol Chem; 285: 21323-21328.

Joel, D.; Annamaria, L.; Bela, I.; Davied, P.V.; et al., (2002): L-carnitine ameliorates gentamicin induced renal injury in rats. Nephrol Dial. Transplant., 17:21222131.

Kelly, DJ.; Skinner, SL.; Cooper, ME. and Wilkinson-Berka, JL. (2000): Differential effects of bosentan and valsartan with respect to progressive diabetic renal pathology in the transgenic (mRen- 2)27-rat model. Kidney Int 57: 1882-1894.

Sakthi SP, Vadivu R, and, Jayshree N (2010). Hypolipidaemic and renoprotective study on the ethanolic and aqueous extracts of leaves of Ravenala madagascariensis Sonn on alloxan induced diabetic rats. International Journal of Pharmaceutical Sciences.; 2(1):44-50.

Sandhya, P. and Varalakshmi, P. (1997): Effect of lipoic acid administration on gentamicin-induced lipid peroxidation in rats. J. Appl. Toxicol., 17: 405-408. 
Suzuki, S.; Takamaura, S.; Yoshida, S.Y.; Niwa, O. and Tamatani, R. (1995): Comparison of gentamicin nephrotoxicity between rats and mice. Camp. Biochem. Physiol. Pharmacol. Toxical. Endocrinal., 112 (1): 15-28.

Vanella, A.; Russo, A. and Barcelona, M.L. (2000): L-carnitine as superoxide scavenger, antioxidant and DNA cleavge protector. Cell Biol. Toxical., 16 (2). 99-104. vascular damage by lisinopril and losartan in the rat. Cardiovasc Res; 29: 543548.

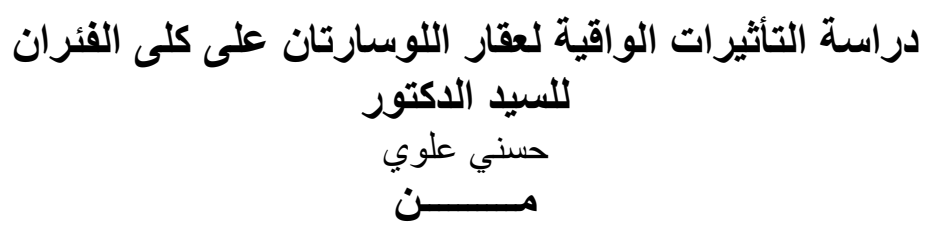

1 قسم الصبيلة الاكلينيكية وصيدلة المستشفيات بجامعة طيبة بالمملكة العربية السعودية

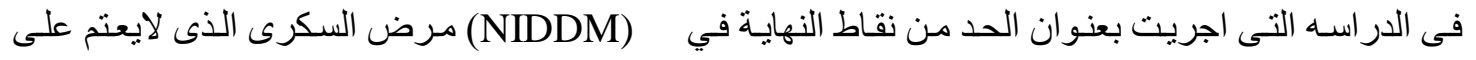

الانسولين وكذلك فى الدر اسة التى استخذمت أنجيوتتسين الثاني المعـاون مثل ( اللوسـارتان ) والدر اسـة تحت اسم در اسـة

(RENAAL)، تبن ان اللوسارتان خفض مخاطر تضـاعف تركيز الكرياتينين في الدم بنسبة 25٪ وكذلك تخفيض عدد

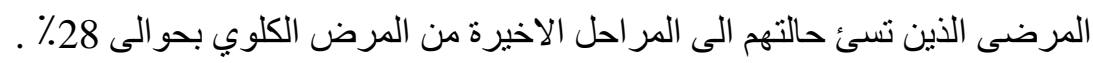

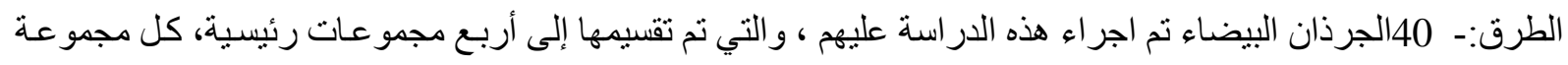

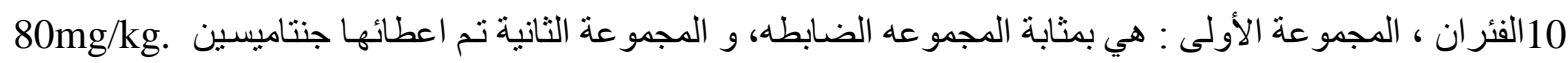
وتم اعطاء المجموعة الثالثة اللوسارتان .في حين تم اعطاء المجموعة الرابعه اللوسارتان مع جنتاميسين .أظهرت النتائج

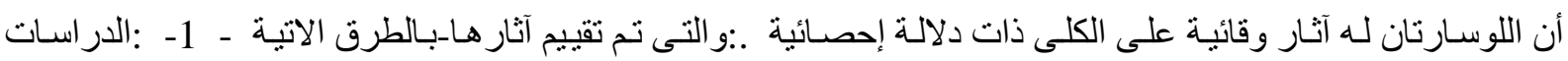

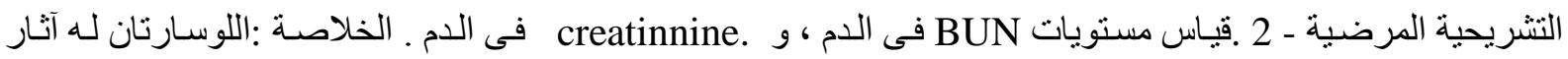

